\title{
Perbaikan Pembungaan Pamelo melalui Aplikasi Strangulasi dan Zat Pemecah Dormansi
}

\author{
Flowering Improvement in Pummelo through Strangulation and Dormancy Breaking \\ Substance Applications
}

Slamet Susanto ${ }^{*}$, Maya Melati ${ }^{1}$, dan Herik Sugeru ${ }^{2}$

Diterima 23 Agustus 2016/Disetujui 9 November 2016

\begin{abstract}
Pummelo productivity is still low, therefore efforts should be made to increase its flowering and production. The objective of study was to determine the effectiveness of strangulation combined with the application of breaking dormancy substances to improve flowering of pummelo. The experiment was conducted in January to November 2015, at the Cikabayan Experimental Research Station, IPB. The carbohydrate and nitrogen analysis was done in laboratory of Postharvest Agriculture Research Institute, Bogor. Three-year-old pummelo grown in field was subjected for this research. Experiment used a completely randomized design (CRD) with two factors. The first factor was treatment to stimulate flowering, consisted of 3 levels i.e. single strangulation, double strangulation and control, and the second factor was the use of dormancy breaking substances, consisted of 3 types i.e. KNO3, Ethepon and BAP. Strangulation was performed by pressing the wire with a diameter of $2.0 \mathrm{~mm}$ into stem as deep as the diameter of the wire. Strangulation was done simultaneously and then released after 3 months. Dormancy breaking substance was applied immediately after releasing the wire for strangulation with the concentration of 200 ppm KNO3, 100 ppm Ethepon or 100 ppm BA. Treatments were replicated 4 times. The results showed that single and double strangulation treatments for 3 months were an effective way to induce flowering of young pummelo trees. Double strangulation produced more flowers as compared to single strangulation. Increased carbohydrate content and $C / N$ ratio in leaves were observed on flower induced trees. Strangulation treatment for 3 months can increase flowering of young pummelo trees. Application of dormancy breaking substances did not have any effect on flowering induction in pummelo.
\end{abstract}

Keywords: carbohydrate content, dormancy breaking substance, flower induction, pummelo, strangulation

\begin{abstract}
ABSTRAK
Produktivitas pamelo masih rendah sehingga perlu upaya peningkatan pembungaan dan produksinya. Penelitian ini bertujuan untuk mengetahui efektivitas strangulasi yang dikombinasikan dengan aplikasi zat pemecah dormansi dalam meningkatkan pembungaan jeruk pamelo. Penelitian dilaksanakan pada bulan Januari sampai Nopember 2015, bertempat di Kebun Percobaan IPB Cikabayan. Analisis karbohidrat dan nitrogen dilakukan di laboratorium BB Pasca Panen, Bogor. Percobaan menggunakan tanaman jeruk pamelo 'Nambangan' berumur 3 tahun dengan Rancangan Acak Lengkap (RAL) dua faktor. Sebagai faktor pertama yaitu perlakuan untuk menstimulasi pembungaan, terdiri atas 3 taraf perlakuan yaitu perlakuan strangulasi tunggal, strangulasi ganda dan kontrol, dan sebagai faktor kedua adalah penggunaan zat pemecah dormansi terdiri atas 3 jenis yaitu KNO3, Ethepon dan BAP. Masing-masing perlakuan diulang 4 kali sehingga terdapat 36 unit percobaan. Strangulasi dilaksanakan dengan melilitkan kawat dengan diameter $2.0 \mathrm{~mm}$ pada batang dengan menekan kawat ke batang sedalam diameter kawat tersebut. Strangulasi dilakukan serentak pada batang, strangulasi dilepas setelah 3 bulan kemudian. Zat pemecah dormansi diaplikasikan segera setelah pelepasan kawat strangulasi dengan konsentrasi masing-masing 200 ppm untuk

\footnotetext{
${ }^{1}$ Departemen Agronomi dan Hortikultura, Fakultas Pertanian, Institut Pertanian Bogor (Bogor Agricultural University)

Jl. Meranti, Kampus IPB Darmaga, Bogor 16680, Indonesia

${ }^{2}$ Laboratorium Kebun Percobaan, Program Studi Agroteknologi, Fakultas Teknologi Industri, Universitas Gunadarma, Kampus F6

Jl. Taman Puspa, Pasir Gunung Selatan, Cimanggis, Depok 16451, Indonesia

Email: slmtsanto@gmail.com (*penulis korespondensi)
} 
KNO3, 100 ppm untuk Ethepon atau 100 ppm untuk BAP. Hasil penelitian menunjukkan perlakuan strangulasi selama 3 bulan merupakan cara efektif menginduksi pembungaan tanaman jeruk pamelo. Perlakuan strangulasi ganda menghasilkan bunga lebih banyak dibandingkan dengan strangulasi tunggal. Tanaman yang telah terinduksi menunjukkan tingginya kandungan karbohidrat pada tajuk tanaman sehingga meningkatkan rasio $\mathrm{C} / \mathrm{N}$. Perlakuan zat pemecah dormansi tidak memberikan pengaruh yang nyata terhadap pembungaan jeruk pamelo.

Kata kunci: kandungan karbohidrat, pamelo, pembungaan, strangulasi, zat pemecah dormansi

\section{PENDAHULUAN}

Pamelo merupakan jenis jeruk yang mempunyai nilai perdagangan yang tinggi. Pamelo potensial dikembangkan, karena karakteristiknya yang khas, yaitu berukuran besar, memiliki rasa segar, dan daya simpan yang lama sampai 4 bulan, dan beberapa kultivar hanya terdapat di Indonesia (Susanto, 2004) serta beberapa diantaranya tidak berbiji (Rahayu et al., 2012). Pamelo tidak berbiji juga dihasilkan negara lain terutama Thailand (Chai et al., 2011, Navareth et al., 2011) dan Jepang (Kim et al., 2011).

Di Indonesia, terdapat berbagai kultivar pamelo (Agisimanto dan Supriyanto, 2007; Purwanto et al., 2002; Susanto et al., 2016). Plasma nutfah pamelo banyak ditemukan di bebeberapa wilayah dengan sentra utama Magetan, Pangkajene dan Kepulauan, Aceh, Pati dan Kudus. Dibandingkan jenis jeruk lain, pamelo mempunyai bobot dan ukuran yang paling besar. Buah pamelo mempunyai bobot berkisar antara 1-7 $\mathrm{kg}$ tergantung pada kultivar. Umumnya buah pamelo mempunyai warna kulit hijau sampai hijau kekuningan dengan warna daging buah mulai dari putih, putih kemerahan, merah sampai merah tua. Demikian pula terdapat variasi dalam jumlah biji dari yang berbiji banyak sampai tidak berbiji sama sekali. Secara umum kriteria buah pamelo yang disukai masyarakat adalah memiliki warna jus merah, tidak getir, mudah dikupas dan tidak atau sedikit berbiji (Susanto et al., 2016).

Luas areal panen pamelo dari 20042014 berfluktuasi antara 4161 - 6177 ha dipengaruhi oleh kondisi iklim tahun berjalan, dengan produksi berkisar antara 64 - 106 ribu ton dan produktivitas 12.03-24.94 ton per ha (Ditjenhort, 2015). Produktivitas ini masih tergolong rendah dibandingkan dengan potensinya yang dapat mencapai 40 ton per ha. Produksi yang masih rendah ini terutama disebabkan karena teknik budidaya yang umumnya masih konvesional dan tidak intensif.

Berbagai upaya perlu dilakukan untuk meningkatkan pembungaan dan produksi pamelo, baik melalui rekayasa terhadap tanaman maupun lingkungan tumbuhnya. Penggunaan interstock dapat memperbaiki pembungaan pamelo (Susanto et al., 2010). Upaya memperbaiki pembungaan juga dapat dilakukan melalui perlakuan strangulasi. Perlakuan strangulasi akan menghambat translokasi fotosintat dari tajuk ke akar sehingga terjadi peningkatan akumulasi karbohidrat di bagian tajuk. Kandungan karbohidrat yang tinggi di tajuk berkorelasi positif dengan peningkatan pembungaan (Goldschmidt, 1999; Goldschmidt dan Golomb, 1982). Hasil penelitian sebelumnya menunjukkan bahwa strangulasi dapat menginduksi pembungaan tanaman manggis (Rai et al., 2004). Hal yang sama dilaporkan Thamrin et al. (2009), strangulasi tunggal pada batang utama menggunakan kawat berdiameter $2.0 \mathrm{~mm}$ dalam waktu tiga bulan mampu meningkatkan pembungaan jeruk besar 'Nambangan'. Namun demikian, belum ada informasi efektivitas strangulasi ganda dibandingkan strangulasi tunggal dalam memperbaiki pembungaan.

Beberapa peneliti telah melaporkan bahwa beberapa bahan kimia seperti KNO3, Ethepon dan BAP dapat mempercepat munculnya tunas beberapa tanaman buah (Poerwanto dan Susanto, 1996; Syahbudin, 1999). Penggunaan beberapa bahan kimia tersebut diharapkan mampu mempercepat pemunculan tunas generatif setelah perlakuan strangulasi. Pada tanaman pamelo yang mendapatkan perlakuan strangulasi, bunga muncul relatif lambat yaitu lebih dari dua bulan setelah pelepasan kawat strangulasi (Thamrin et al., 2009). Penelitian ini bertujuan untuk mengetahui efektivitas strangulasi tunggal dan ganda dikombinasikan dengan zat 
pemecah dormansi dalam meningkatkan dan mempercepat pembungaan jeruk pamelo.

\section{BAHAN DAN METODE}

Penelitian dilaksanakan pada bulan Januari sampai Desember 2015. Bahan yang digunakan dalam penelitian ini yaitu tanaman jeruk Pamelo umur 3 tahun asal okulasi dengan batang bawah Javansche Citroen yang ditanam di Kebun Percobaan IPB Cikabayan dengan pertumbuhan yang relatif seragam. Tanaman ditanam dengan jarak tanam $3 \mathrm{~m} \mathrm{x} 4 \mathrm{~m}$. Terdapat 36 tanaman yang digunakan untuk percobaan. Analisis karbohidrat dan nitrogen dilakukan di laboratorium BB Pasca Panen Bogor.

Percobaan menggunakan Rancangan Acak Lengkap (RAL) dengan dua faktor yang dicobakan yaitu perlakuan untuk menstimulasi pembungaan, terdiri atas 3 taraf perlakuan yaitu perlakuan strangulasi tunggal, strangulasi ganda dan kontrol, dan sebagai faktor kedua adalah penggunaan zat pemecah dormansi terdiri atas 3 jenis yaitu $\mathrm{KNO}$, Ethepon dan BAP. Setiap perlakuan diulang 4 kali sehingga terdapat 36 satuan percobaan. Setiap satuan percobaan menggunakan satu tanaman. Strangulasi dilaksanakan dengan melilitkan kawat dengan diameter $2.0 \mathrm{~mm}$ pada batang dengan menekan kawat ke batang sedalam diameter kawat tersebut. Strangulasi dilakukan serentak pada batang utama, strangulasi dilepas setelah 3 bulan kemudian. Zat pemecah dormansi diaplikasikan segera setelah perlakuan strangulasi dilepas dengan konsentrasi masing-masing 200 ppm untuk KNO3, 100 ppm untuk Ehepon dan 100 ppm untuk BAP.
Tanaman dipelihara sesuai dengan standar yang dilakukan petani yang meliputi pemupukan, penyiraman dan pengendalian organisme pengganggu tanaman. Pemupukan dengan pupuk kandang ayam dilakukan setahun 2 kali setahun dengan dosis 20 $\mathrm{kg} / \mathrm{tanaman} / 6$ bulan. Pupuk NPK diberikan setiap 2 bulan dengan dosis $20 \mathrm{~g} /$ tanaman/ 2 bulan. Penyiraman tanaman dilakukan terutama pada musim kemarau dengan frekuensi satu minggu sekali. Pengendalian organisme pengganggu tanaman dilakukan secara manual dan kimia sesuai kebutuhan.

Pengamatan meliputi peubah vegetatif dan generatif, kandungan hara $\mathrm{N}$ dan karbohidrat daun. Kandungan hara $\mathrm{N}$ diukur dengan metode Kjeldahl (William, 1984) dan kandungan karbohidrat daun diukur dengan metode Somogyi-Nelson (Hodge dan Hofreiter, 1964), dilakukan pada akhir perlakuan strangulasi.

\section{HASIL DAN PEMBAHASAN}

\section{Pertumbuhan Tunas Vegetatif}

Perlakuan strangulasi secara nyata menekan jumlah tunas vegetatif yang muncul dan panjang total tunas vegetatif dibandingkan kontrol. Namun demikian, perlakuan zat pemecah dormansi tidak memberikan pengaruh yang nyata terhadap pemunculan tunas vegetatif dan panjang tunas (Tabel 1). Jumlah tunas vegetatif yang lebih sedikit akibat perlakuan strangulasi diduga akibat munculnya tunas generatif sebagai pesaing tunas vegetatif. Sedikitnya tunas vegetatif yang muncul pada perlakuan strangulasi juga dinyatakan pada penelitian yang dilakukan sebelumnya (Susanto et al., 2002; 2004).

Tabel 1. Jumlah dan panjang tunas vegetatif

\begin{tabular}{lccc}
\hline \multicolumn{1}{c}{ Perlakuan } & $\begin{array}{c}\text { Jumlah Tunas } \\
\text { Vegetatif }\end{array}$ & $\begin{array}{c}\text { Panjang per Tunas } \\
(\mathrm{cm})\end{array}$ & $\begin{array}{c}\text { Total Panjang Tunas } \\
(\mathrm{cm})\end{array}$ \\
\hline Strangulasi & $32.6 \mathrm{a}$ & 11.6 & $378.6 \mathrm{a}$ \\
$\quad$ Tanpa Strangulasi & $20.3 \mathrm{~b}$ & 10.8 & $219.2 \mathrm{~b}$ \\
Strangulasi Tunggal & $19.3 \mathrm{~b}$ & 12.2 & $235.2 \mathrm{~b}$ \\
$\quad$ Strangulasi Ganda & & & \\
Aplikasi ZPD & 25.3 & 11.8 & 298.5 \\
KNO3 & 22.9 & 10.6 & 242.7 \\
Ethepon & 23.2 & 12.1 & 280.7 \\
BAP & 23.5 & 11.6 & 272.6 \\
Kontrol & $\mathrm{ns}$ & $\mathrm{ns}$ & $\mathrm{ns}$ \\
\hline
\end{tabular}

Keterangan: Angka yang diikuti oleh huruf yang sama pada kolom yang sama tidak berbeda nyata pada uji DMRT taraf $5 \%$. 


\section{Pertumbuhan Generatif}

Perlakuan strangulasi berpengaruh sangat nyata terhadap jumlah tanaman berbunga, jumlah tunas generatif, dan waktu berbunga, jumlah inflorescence dan bunga serta fruit set (Tabel 2 dan Tabel 3). Lebih dari 75\% tanaman yang mendapatkan perlakuan strangulasi berbunga, sedangkan pada tanaman kontrol tidak berbunga sama sekali. Tunas generatif, inflorescence dan bunga yang muncul pada tanaman yang mendapatkan perlakuan strangulasi masih rendah, masingmasing berkisar antara 8-13 tunas generatif per tanaman dan jumlah inflorescence 14.3-20.3 dengan jumlah bunga berkisar 46.2-64.3 bunga per tanaman. Hal ini diduga karena tanaman yang digunakan masih muda dan baru melalui proses transisi menuju fase dewasa. Tanaman yang mendapatkan strangulasi ganda menghasilkan bunga lebih banyak dibandingkan strangulasi tunggal. Tidak terdapat perbedaan yang nyata antar tanaman yang mendapatkan perlakuan zat pemecah dormansi baik pada jumlah tunas vegetatif maupun tunas generatif. Pada seluruh perlakuan waktu berbunga berkisar 8.8-9.2 MSP dan fruit set berkisar antara 7.1-9.4\% tidak menunjukkan perbedaan yang nyata antar perlakuan.

Thamrin et al. (2009) menyatakan jumlah bunga pada tanaman yang distrangulasi pada cabang primer menghasilkan buah dan produksi lebih banyak dan berbeda sangat nyata dibandingkan dengan tanaman kontrol yang tidak terbentuk bunga dan buah. Waktu pertama munculnya bunga dalam penelitian ini adalah 8.8 MSP. Waktu muncul bunga pertama tersebut, tidak jauh berbeda dengan perlakuan strangulasi pada tanaman dewasa kultivar 'Nambangan' yang berbunga pada 8.6 MSP (Susanto et al., 2002).

Tabel 2. Jumlah tanaman berbunga, jumlah tunas generatif dan waktu berbunga

\begin{tabular}{|c|c|c|c|}
\hline Perlakuan & $\begin{array}{c}\text { Jumlah Tanaman Berbunga/ } \\
\text { Total Tanaman }\end{array}$ & $\begin{array}{c}\text { Jumlah Tunas Generatif } \\
\text { per Tanaman }\end{array}$ & $\begin{array}{l}\text { Waktu Berbunga } \\
\text { (MSP) }\end{array}$ \\
\hline \multicolumn{4}{|l|}{ Strangulasi } \\
\hline Tanpa strangulasi & $0 / 12$ & $0 \mathrm{~b}$ & \\
\hline Strangulasi Tunggal & $8 / 12$ & $8.2 \mathrm{a}$ & $9.2 \mathrm{a}$ \\
\hline Strangulasi Ganda & $11 / 12$ & $13.0 \mathrm{a}$ & $8.8 \mathrm{a}$ \\
\hline \multicolumn{4}{|l|}{ Aplikasi ZPD } \\
\hline KNO3 & $5 / 9$ & 6.02 & 8.3 \\
\hline Ethepon & $5 / 9$ & 5.60 & 9.3 \\
\hline BAP & $5 / 9$ & 5.92 & 7.9 \\
\hline \multirow[t]{2}{*}{ Kontrol } & $4 / 9$ & 5.81 & 8.2 \\
\hline & & ns & ns \\
\hline
\end{tabular}

Keterangan: Angka yang diikuti oleh huruf yang sama pada kolom yang sama tidak berbeda nyata pada uji DMRT taraf 5\%. MSP: Minggu setelah perlakuan.

Tabel 3. Jumlah tunas generatif, waktu berbunga, jumlah bunga dan fruit set

\begin{tabular}{lccc}
\hline Perlakuan & $\begin{array}{c}\text { Jumlah } \\
\text { Inflorescence }\end{array}$ & $\begin{array}{c}\text { Jumlah } \\
\text { Bunga }\end{array}$ & $\begin{array}{c}\text { Fruit set } \\
(\%)\end{array}$ \\
\hline Strangulasi & $0 \mathrm{~b}$ & $0 \mathrm{~b}$ & - \\
$\quad$ Tanpa strangulasi & $14.3 \mathrm{ab}$ & $46.2 \mathrm{a}$ & 9.4 \\
Strangulasi Tunggal & $20.3 \mathrm{a}$ & $64.3 \mathrm{a}$ & 7.1 \\
$\quad$ Strangulasi Ganda & 10.7 & 28.6 & 7.3 \\
Aplikasi ZPD & 12.4 & 32.3 & 8.6 \\
KNO3 & 9.8 & 26.9 & 8.9 \\
Ethepon & 11.2 & 27.4 & 7.6 \\
BAP & $\mathrm{ns}$ & $\mathrm{ns}$ & $\mathrm{ns}$ \\
Kontrol & $\mathrm{ns}$ & \\
\hline
\end{tabular}

Keterangan: Angka yang diikuti oleh huruf yang sama pada kolom yang sama tidak berbeda nyata pada uji DMRT taraf $5 \%$. 
Tabel 4. Kandungan nitrogen, karbohidrat daun dan rasio C/N

\begin{tabular}{lccc}
\hline \multicolumn{1}{c}{ Perlakuan } & $\begin{array}{c}\text { Karbohidrat } \\
(\%)\end{array}$ & $\begin{array}{c}\text { Nitrogen } \\
(\%)\end{array}$ & $\begin{array}{c}\text { Rasio } \\
\text { C/N }\end{array}$ \\
\hline Srangulasi & & & $3.47 \mathrm{~b}$ \\
$\quad$ Tanpa strangulasi & $10.93 \mathrm{~b}$ & 3.15 & $3.92 \mathrm{a}$ \\
$\quad$ Strangulasi tunggal & $11.84 \mathrm{a}$ & 3.02 & $3.83 \mathrm{a}$ \\
$\quad$ Strangulasi ganda & $11.81 \mathrm{a}$ & 3.08 & 3.81 \\
Zat Pemecah Dormansi & & & 3.68 \\
$\quad$ KNO3 & 11.59 & 3.04 & 3.67 \\
Ethepon & 11.46 & 3.11 & 3.74 \\
BAP & 11.32 & 3.08 & $\mathrm{~ns}$ \\
\hline Kontrol & 11.45 & 3.06 & $\mathrm{~ns}$ \\
\hline Interaksi & $\mathrm{ns}$ & $\mathrm{ns}$ & $\mathrm{n}$ \\
\hline
\end{tabular}

Keterangan: Angka yang diikuti oleh huruf yang sama pada kolom yang sama tidak berbeda nyata pada uji DMRT taraf $5 \%$.

\section{Kandungan Karbohidrat, Nitrogen dan Rasio C/N}

Kandungan karbohidrat dan rasio $\mathrm{C} / \mathrm{N}$ tanaman yang mendapat perlakuan strangulasi nyata lebih tinggi dibandingkan tanaman kontrol. Namun demikian, antara perlakuan strangulasi tunggal dan ganda tidak menunjukkan perbedaan yang nyata. Perlakuan strangulasi tidak menunjukkan pengaruh yang berbeda pada kandungan $\mathrm{N}$ daun dibandingkan kontrol. Perlakuan zat pemecah dormansi tidak menunjukkan perbedaan yang nyata antar perlakuan baik pada kandungan karbohidrat, nitrogen maupun rasio $\mathrm{C} / \mathrm{N}$ (Tabel 4). Hubungan kandungan karbohidrat daun yang tinggi dengan terjadinya pembungaan pada jeruk juga dilaporkan oleh Goldschmidt (1999) dan Goldschmidt dan Golomb (1982).

Strangulasi yang bertujuan untuk menghambat translokasi fotosintat dari tajuk ke akar dapat menginduksi pembungaan, diduga berhubungan dengan peningkatan kandungan karbohidrat total dan nisbah $\mathrm{C} / \mathrm{N}$ daun. Berdasarkan penelitian Thamrin et al., (2009), perlakuan strangulasi mampu meningkatkan karbohidrat di tajuk, sehingga meningkatkan rasio $\mathrm{C} / \mathrm{N}$ daun pada tanaman. Tingginya rasio $\mathrm{C} / \mathrm{N}$ merupakan faktor yang mengakibatkan terjadinya induksi pembungaan tanaman yang nampak dari munculnya tunas generatif. Pada jeruk pembentukan bunga sangat erat kaitannya dengan kandungan karbohidrat daun (Thamrin et al., 2009, Garcia-Luis et al., 1995; Goldschmidt et al., 1985; Susanto et al., 2002). Putra (2002) menyatakan bahwa perlakuan strangulasi meningkatkan pembungaan jeruk besar 'Nambangan' dan bunga muncul 5.6 hari lebih cepat dibandingkan kontrol. Pada percobaan ini, kecepatan munculnya bunga pada tanaman yang mendapat perlakuan strangulasi tidak dapat dibandingkan dengan kontrol, karena tanaman kontrol tidak menghasilkan bunga sama sekali. Walaupun tunas bunga muncul sekitar 8 minggu setelah berakhirnya perlakuan strangulasi, perlakuan zat pemecah dormansi tidak mampu mempercepat pemunculan tunas bunga pada tanaman yang mendapat perlakuan strangulasi. Hal ini diduga karena perlakuan strangulasi tidak mengakibatkan dormansi.

\section{KESIMPULAN}

Perlakuan strangulasi selama 3 bulan merupakan cara yang efektif menginduksi pembungaan pada tanaman jeruk pamelo. Tanaman yang telah terinduksi menunjukkan tingginya kandungan karbohidrat pada tajuk tanaman sehingga meningkatkan rasio $\mathrm{C} / \mathrm{N}$. Pembungaan mulai terjadi pada 8.8 MSP dengan fruit set cukup tinggi sebesar 7-9\%. Perlakuan strangulasi ganda lebih efektif dalam meningkatkan pembungaan dibandingkan dengan strangulasi tunggal. Perlakuan ZPD tidak memberikan pengaruh yang nyata terhadap percepatan pembungaan.

\section{UCAPAN TERIMAKASIH}

Penelitian ini terlaksana dengan pendanaan dari Direktoral Jenderal Pendidikan Tinggi, Kementerian Pendidikan dan Kebudayaan melalui Hibah Kompetensi tahun 2015. 


\section{DAFTAR PUSTAKA}

Agisimanto, D., A. Supriyanto. 2007. Keragaman genetik pamelo Indonesia berdasarkan primer random amplified polymorphic DNA. J. Hort. 17: 1-7.

Chai, L., X. Ge, M. K. Biswas, Q. Xu, X. Deng. 2011. Self-sterility in the mutant 'Zigui shatian' pummelo (Citrus grandis Osbeck) is due to abnormal post-zygotic embryo development and not selfincompatibility. Plant Cell Tissue Organ Cult. 104: 1-11.

[Ditjenhort] Direktorat Jenderal Bina Produksi Hortikultura. 2015. Daerah sentra jeruk. http:/hortikultura.deptan.go.id [23 Februari 2016].

Garcia-Luis, A., F. Fornes, J. L. Guardiola. 1995. Leaf carbohydrate and flower formation in citrus. J. Amer. Soc. Hort. Sci. 120: 222-227.

Goldschmidt, E.E. 1999. Carbohydrate supply as a critical factor for citrus fruit development and productivity. HortScience. 34(6): 1020-1024.

Goldschmidt, E.E., A. Golomb. 1982. The carbohydrate balance of alternate bearing citrus trees and the significance of reserves for flowering and fruiting. J. Amer. Soc. Hort. Sci. 170: 206-208.

Goldschmidt, E.E., N.Aschkenazi, Y.Herzano, A.A. Schaffer, P. Monselise. 1985. A role for carbohydrtae levels in the control of flowering in citrus. Scientia Hort. 26: 159-166.

Kim, J.H., T. Mori, A. Wakana, B.X. Ngo, K. Sakai, K. Kajiwara. 2011. Determination of self-incompatible citrus cultivars with $\mathrm{S} 1$ and/or $\mathrm{S} 2$ alleles by pollination with homozygous S1 seedlings (S1S1 or S2S2) of 'Banpeiyu' pummelo. J. Jpn. Soc. Hort. Sci. 80: 404-413.

Nartvaranant, P., K. Nartvaranant. 2011. Analysis based on AFLP markers of the genetic variations and their relationships for pummelo cultivars grown in the central region of Thailand. Songklanakarin. J. Sci. Technol. 33: 499-508.

Poerwanto, R., S. Susanto. 1996. Pengaturan pembungaan dan pembuahan jeruk dengan paclobutrazol dan zat pemecah dormansi. J. Pert. Indonesia. 6: 39-44.

Purwanto, E., Sukaya, A. Setianto, H. Santoso. 2002. Identifikasi berdasarkan penanda isozim terhadap plasma nutfah jeruk besar (Citrus maxima Merr.). BioSmart. 4: 44-47.

Putra, G.A. 2002. Pengaruh strangulasi terhadap pembungaan jeruk besar 'Nambangan'. [Tesis]. Institut Pertanian Bogor. Bogor.

Rahayu, A., S. Susanto, B.S. Purwoko, I.S Dewi. 2012. Karakter morfologi dan kimia kultivar pamelo (Citrus maxima (Burm.) Merr.) berbiji dan tanpa biji. J. Agron. Indonesia. 40(1): 48-55.

Rai, I.N., R. Poerwanto, L.K. Darusman, B.S Purwoko. 2004. Pengaruh pembungaan tanaman manggis (Garcinia mangostana L.) di luar musim dengan strangulasi, serta aplikasi paklobutrazol dan ethepon. Bul. Agron. 32(2): 12-20.

Susanto, S., A. Rahayu, K.N. Tyas. 2016. Pamelo Indonesia dan Kajian Ekofisiologisnya. IPB Press. Bogor.

Susanto, S., H. Sugeru, S. Minten. 2010. Pertumbuhan vegetatif dan generatif batang atas jeruk pamelo 'Nambangan' pada empat jenis interstok. J. Hort. Indonesia. 1(2): 53-58.

Susanto, S., S. Minten, G. Ardhaniputera. 2004. Pengaruh lama waktu strangulasi terhadap pembungaan jeruk besar 'Nambangan'. Seminar dan Kongres PERHORTI. Jakarta. 23 September 2004.

Susanto, S., S. Minten, A. Mursyada. 2002. Pengaruh strangulasi terhadap pembungaan jeruk besar (Citrus grandis (L.) Osbeck) kultivar Nambangan. J. Agrotropika. 7(1): 34-37. 
Syahbudin. 1999. Studi stimulan pembungaan jeruk siem dengan pacloutrazol dan zat pemecah dormansi ethepon. [Tesis]. Program Pasca Sarjana. Institut Pertanian Bogor. Bogor.

Thamrin, M., S. Susanto, E. Santosa. 2009. Efektivitas strangulasi terhadap pembungaan tanaman jeruk pamelo 'Cikoneng' pada tingkat pembuahan sebelumnya yang berbeda. J. Agron. Indonesia. 37(1): 4045.

Wiliam, S. (ed.). 1984. Official methods of analysis of the Association of Official Analytical Chemist. 14th. Ed. Assoc. Off. Anal. Chem. Inc. Va. pp. 16-17. 